\title{
The Impacts of Globalization That Has Brought Up by Companies in Tanzania. A Case Study of Bakhresa Food Production Company.
}

\author{
Herieth Eliapenda Mbonea Qian Chen \\ School of Economics and Management, Zhejiang University of Science and Technology; Hangzhou, CN
}

\begin{abstract}
Globalization has a lot of controversies with regard to the rise of global Development in Companies. Many Companies, Industry and sectors in the world has been affected by Globalization. This paper critically assesses the influence of Globalization in Companies of Tanzania. Well, there are many Companies in Tanzania it's so broad I will tackle on Food Company which is Bakhresa. This paper therefore is trying to touch on areas which are affected by Globalization Especially Food Companies. This is a result of which comes from a certain level of influence such that consequences are either bad or good. Moreover, it can be said that Globalization in Tanzania has played a significant role in raising most of the living standard in many areas.
\end{abstract}

Keywords: Globalization, Companies, Businesses, Development, Effects of Globalization, Tanzania, Bakresah, Food, Industry/Companies(y)

DOI: $10.7176 / \mathrm{JESD} / 11-20-09$

Publication date:October $31^{\text {st }} 2020$

\subsection{INTRODUCTION}

The term globalization is certainly not new and has received major attention especially in the last few decades. It is on record that globalization is taking place at a faster pace (Dreher et al., 2008). The term Globalization captures the attention of everyone and especially economic development researchers. Some studies show that Globalization has widened the gap between rich and poor countries in its relentless progression while others are unclear about its effect. However, despite the prior prosperity promises of Globalization and the benefits of the impacts of globalization that has brought up by the Food Companies of Tanzania has a background so I'll explain it in-short as Globalization is the Process of interaction and integration among people companies and governments worldwide. According to Colle (2000) has argued that these are flow of financial and economic resources with particular reference to the flow of goods and services and to a large extent, labour, technology, communications and information technology, the spread of culture from one corner of the world to the other and global diffusion of religious ideas as well as ideologies. Charles W.L Hill simply defines Globalization as "the shift towards a more integrated and inter-dependent world economy" (quoted in Hill, 2007 p.5)

The concept of Globalization is one that has become widely used in businesses, Politics, debates and media over the past few years. Globalization is created by the coming together social, economic, cultural, political factors. It has been driven forward above all by the development of communication and information technologies that have intensified the scope and speed of interaction between people all over the world.9Giddens, 2001) This now gives us a light to the benefits of Globalization. The benefits of market lies in the fact that Globalization is merging historic distinct and separate national markets into one huge global marketplace. Consumer products such as CocaCola, McDonalds's, Starbucks and Sony are frequently held up as prototypical examples of this trend. These firms are more than just benefactors of this trend. They are also facilitators of it. By offering the same products worldwide, they help to create global market. (Department of Commerce, 2003)

The purpose of this research is to assess the positive and negative effects of Globalization in the companies of Tanzania. I have given an example of Bakresah food Company in Tanzania. Tanzania is one among the countries in African continent with better performance in terms of GDP growth and attracting foreign inflows due to Globalization. Food production play an important role in the national economic development of Tanzania. Hence many of them have great growth potential. Bakhresa Group of Company is an industrial conglomerate based in Tanzania, East Africa. Owned by an entrepreneur and Tanzanian billionaire Said Salim Bakhresa, the business is one of the largest in the region. It is composed of Bakhresa \& Co.'s, Bakhresa Food Products ltd and large collection of other companies of various industries such as transport and logistics and real estate. The group started in 1980's and ever since it has been expanding its borders from Tanzania to the neighbouring countries and hence increase of market demand throughout. Bakhresa group of Companies has operates recently in Tanzania because that is the headquarter, Zanzibar, Mozambique, Zambia, Malawi, Kenya, Uganda, Rwanda, Burundi and South Africa. Bakhresa Group of Company involvled in agribusiness, logistics, oil trading, beverages, packaging and recycling.

It has also invested in the operation of a marine service that has tours to and from the island of Zanzibar. The main offices are on the mainland coast of Dar-es-Salaam where one can process tickets and further information 
necessary for future trip. There are range of companies under its umbrella and with investments primarily in the Food and Beverage Sector, Packaging, Logistics, Marine Passenger Services, Petroleum and Entertainment. The products and services provided by the group are:Wheat Flour, Wheat Bran, Puratha(Chapati), Maize Flour, Maize Bran, Biscuits \& Bakery Products, Carbonated Soft Drinks \& Malt Flavoured Products, Natural Fruit Juices.

Food production play an important role in the national economic development of Tanzania. Hence many of them have great growth potential. Bakhresa Group of Company is composed of Said Salim Bakhresa \& Co.'s, Bakhresa Food Products ltd and large collection of other companies of various industries such as transport and logistics and real estate. The group started in 1980's and ever since it has been expanding its borders from Tanzania to the neighbouring countries and hence increase of market demand throughout. Bakhresa group of Companies has operates recently in Tanzania, Zanzibar, Mozambique, Zambia, Malawi, Kenya, Uganda, Rwanda, Burundi and South Africa. Bakhresa Group of Company involvled in agribusiness, logistics, oil trading, beverages, packaging and recycling.

\subsection{Problem Statement}

I'll talk about the issues that are going to be raised. For example, Globalization is one main factor that nations in trade and services are being demanded. Globalization has changed the demand of goods. For instance; Globalization has brought more issues to mankind. Some previous studies examined the positive and negative impacts of globalization in the enterprises as a Companies like Bakhresa but they have not talked about some of the Strategies of controlling the negative effects of globalization in Bakhresa Company. Therefore, this study designs those strategies so I'll talk about it too.

Bakhresa Company encounters many barriers in the operation of its diverse businesses in the SADC region. Among the challenging are:

- Poor and inadequate infrastructure;

- Lack of harmonised taxation regimes;

- Regulatory uncertainty

- Corruption

- Bureaucracy

- Non-tariff barriers

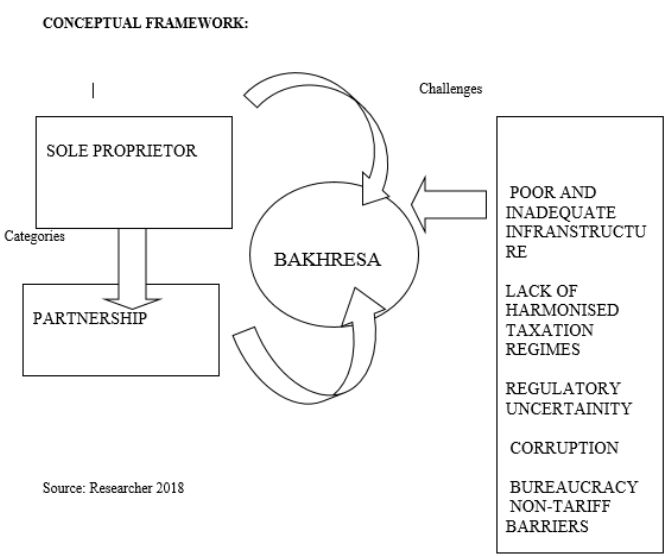

\subsection{Objective}

-How Globalization is affecting Food Companies in Tanzania

-How Globalization affect the International trade

-How Globalization can either affect the Living standard of People

-How Globalization is affecting technical change

-How Globalization is making an impact on Foreign Direct Investment

\subsection{Negative effect of Globalization in Bakhresa Food Company}

I will explain and mention few of the negative effects as follows; Environmental damage: This is where by Through Bakhresa food t company produce some food products it comes a time whereby through globalization it takes advantage of lax regulation in the process they manufacture products that are harmful to the environment hence diseases. Less job opportunities; Bakhresa food company in Tanzania is setting up in places with that is conducive whereby the wages and manufacturing jobs are cheaper hence this means less opportunities in the company that produce higher manufacturing jobs so these company loose and if they gain its very little.

Through Globalization in Bakhresa food Company this has eased international trade and commerce, 
facilitated foreign investment and the flow of capital while calling for greater accountability and responsiveness of leaders to their people, Globalization has often pressed African leaders to adopt policies and measures that are diametrically opposed to the feelings and sentiments of vast majority of their people.

In additional point of view, we can clearly see that education has increased in recent years, because globalization has a catalyst to the jobs that require higher skills set. This demand allowed people to gain higher education. Health and education are basic since you can't have poor health and still bring good production in Companies.

great changes have taken place in the family life, young people trying to leave their families and live alone when they get 18 years old, and the extended family tends to become smaller than before (Kurdishglobe, 2010

\section{LITERATURE REVIEW}

Globalization has shown an important role in promoting development in many Companies in Tanzania, not only that also it has made a good impression in many sectors which lead to an increase in investments. This section review various theoretical and empirical literatures and defines key terms used in this study. This chapter reviews the existing literature on how Globalization has affect Bakhresa food Company in Tanzania, Globalization definitions, challenges, importance, policy and other relevant aspects to this study are also highlighted. According to Banjo (2000), he emphasizes that the process of globalization is impelled by the series of cumulative and conjectural crisis in the international division of labor and global distribution of economic and political power, in global distribution of economic and political power. Globalization of the economy includes the growing of internationalization of trade, capital investment, finance, business and the technology of production (Wade, 1996). According to Thirlwall (2003:13) " Developing countries depend on developed countries for resource flows and technology, but developed countries depend heavily on developing countries for raw materials, food and oil, and as markets for industrial goods". One the most important advantages of globalization are goods and people are transported easier and faster as a result free trade between countries has increased, Tanzania as a vivid good example it has experienced that hence many companies get easier access to expand more and it decreased the possibility of getting losses.

\subsection{Positive Effects of Bakhresa Food Company.}

It gives Access to larger market: This is whereby Through globalization most places in Tanzania and in Bakhresa food company at large have an access of a bigger consumer base, instead of not only selling food products in Tanzania but to other countries outside Tanzania hence we get Foreign currency in our country. It Provides Cheaper Goods for consumers: This is whereby because of globalization Bakhresa food company are locating to most places where their cost of production is lower so what they do they offer or sell cheaper as in affordable products because they are not expensive so this attracts more consumers hence consumers get the products of quality in a lower prices. It creates innovation:

This is whereby if a group of people or one person wants to open or start a company through globalization they may grab some new ideas and skills in Bakhresa food Company on how to run it effectively for more output or output in future, in addition as people get used of it they may spread it to one another basically for more success in Tanzania at large. It provides peace and unity: Through globalization it brings awareness of being united as one whereby while working in Bakhresa food Company and also this is happening most places in Tanzania whereby people may tackle common goals together and lifting each other for everyone to succeed in life basically in business. It leads to better economies: This is whereby many multi nation's heading to Africa example Tanzania to tap the consumer base in this part of the world that's when more job opportunities arise in Tanzania such as many people work $n$ Bakhresa food Company so they are being created to help people to get better wages and improve their living standard.

\subsection{Theoretical Literature Review \\ 2.2.1 Theories of Globalisation}

\section{a) Theory of Marxism}

Marxism is principally concerned with modes of production, social exploitation through unjust distribution, and social emancipation through the transcendence of capitalism. Marx himself anticipated the growth of globality that capital by its nature drives beyond every spatial barrier to conquer the whole earth for its market. Accordingly, to Marxists, Globalisation happens because trans-world connectivity enhances opportunities of profit making and surplus accumulation.

\section{b) Theory of Constructivism}

Globalisation has also arisen because of the way that people have mentally constructed the social world with particular symbols, language, images and interpretation. It is the result of particular forms and dynamics of consciousness. Patterns of production and governance are second-order structures that derive from deeper cultural and socio-psychological forces. 


\section{c) Theory of Political Realism}

Advocates of this theory are interested in questions of state power, the pursuit of national interest and conflict between states. According to them states are inherently acquisitive and self-serving, and heading for inevitable competition of power. Some of the scholars stand for a balance of power, where any attempt by one state to achieve world dominance is countered by collective resistance from other states.

\section{RESEARCH METHODOLOGY}

The research for this study was exploratory research design because with this research problem, there fewer studies to refer to as to reveal the positive and negative effects of Globalisation that has brought up by Companies in Tanzania. The study area in which this study was undertaken was Tanzania as to being one of developing country found in East Africa, to the nature of this study as exploratory study, from sources like World Bank, IMF Bank of Tanzania and TIC. Thus, method which was used to collect those data was content analysis method. Contentanalysis consists of analysing the contents from the documentary materials such as books, magazines, newspapers and the contents of all other verbal materials which can be either spoken or printed. In line with similar studies on Globalization and Companies in Tanzania. The study uses a linear regression approach to determine the positive and negative effects of Globalization and Companies in Tanzania. Taking a little peak on Globalization and Companies.

\subsection{Study Area}

This study will be conducted within Nyamagana Council and Ilemela Council in Mwanza region in the country of Tanzania. Tanzania is one among countries, It is located in East part of Africa specifically with a seaboard of Indian Ocean coastline approximately 1,424 kilometres or 885 miles long. Tanzania is a union formed in 1964 between the mainlands a German colony and later a British protectorate formerly known as Tanganyika and the islands of Zanzibar, Pemba and several smaller islands like Unguja and Mafia. Mainland Tanganyika covers than 99 percent of the combined territories total area. Mafia island is administered from the mainland while Zanzibar and Pemba islands have separate government. Tanzania has 26 cities and since 1974 Dodoma city it has been the designated official capital city of Tanzania. It is centrally located on the mainland. Dar es Salaam, however remains the seat of most government administration as well as being the largest city and port in the country of Tanzania. The current population of Tanzania is $58,766,232$ as of $11^{\text {th }}$ Wednesday 2019 based on world meters elaboration of the latest United Nations data.

\subsection{Study Type}

This will be a cross section study design of Globalization in Bakhresa Company in Tanzania. The design will allow direct collection of qualitative data on positive and negative effects of Globalization that has brought by companies in Tanzania, as a case study in Bakhresa Company. This will be sufficient to address the intended research questions in this paper.

\subsubsection{Research Design}

Methodology is a general approach to study a research topic. Whereby it gives light on how to go about studying the phenomenon. The methodology that I will choose it will guide the techniques for the data gathering and data analysis. Positivism, which seeks to discover laws by qualitative methods, is an example of a methodology, which I basically chose it for my research, I will be gathering data through different websites and therefore obtaining what I want specifically.

Qualitative research according to John Creswell it is a primary data collection. This helps to gain an understanding of underlying motivations, reasons and opinion. It provides insights into the problem, this method can help to develop ideas or in other word hypothesis for potential quantitative research. It is also used to uncover trends in onions and thoughts, also by dive deeper into the problem.

Key Variables Data.

\section{$>$ Dependent variable.}

$>$ Categories of different Globalization.

\subsection{Location: Urban areas}

A structured questionnaire will be developed in English and translated into Swahili, the language spoken by all Tanzanians. A back translation will be done to check for validity. The questionnaire will collect information on different companies on how globalization has made an impact, location of companies, how to solve problems and which techniques are best and many others. After acquiring permission from the authorities, a structure questionnaire will be administered among selected population elements. The investigator will work with research assistant to address any question that might arise. 


\subsection{Research Instruments}

\subsubsection{Questionnaires.}

The study will gather some data through the use of a structured questionnaire to collect data from most companies on how globalization has played part. A questionnaire is a list of questions, which seeks to source data from the people views, opinions or ideas, to answer certain laid down research. A structured questionnaire was advocated by Emile Durkheim (1858-1917), it is a positivist research method whereby it includes the low level of involvement of researcher and high number of respondents. There are different types of questionnaires such as telephone questionnaires, electronic questionnaires and postal questionnaires. For my case of this research paper I will use electronic questionnaires whereby I will be administering questions by email. Geoff Payne and Judy Payne (2004) suggests that this is useful way of contacting dispersed groups of people or those who might not wish to be questioned face-to-face.

\subsection{Data processing and Analysis}

I will use a Primary data, these are data that are collected individually or directly from the source, and in other word is called a raw data. These are the first hand data. Primary data analysis refers to the assessment and interpretation of a set of primary data and preparing report on them

\subsection{DATA ANALYSIS}

The data was analysed using questionnaires whereby the data was obtained by many respondents according to their level of understanding and experience in the company. This study it is comprises both quantitative and qualitative approaches for analysing and presenting the findings, this is simplified the discussion and presentation of the information by using STATA econometric software. The researcher used a time series data from 2000 to 2019 in the analysis. In line with similar studies on Globalization and Bakhresa Food Company.

Bakhresa Group has successfully by having a lot of different disciplines as follow; Project leader, Commercial scanner this contributes to understanding of innovation process. Many firms that are in the Bakhresa food Company they do not operate in vacuum. What they do is they trade with each other, they work as a team work in some areas and compete in others. The function of some other firms is a huge major factor in understanding innovation. Well speaking of Organizational behaviour of Bakhresa Food Company it has a curial role on playing to implement and understand activities which has been essential to ensure success. Significant discoveries and innovations have been with the Bakhresa Food Company.

The Bakhresa Group currently brings together 19 companies, with operations in 8 broad areas, including grain milling and storage, food products, packaging, plastic recycling, logistics and transport, telecommunications, real estate and petroleum. Their annual turnover is over USD 300milion and they employ over 2000 employees. While the company is manged by his sons, Bakhresa owns the company itself. Its daily capacity for manufacturing is 2100 metric tons and made sales of $\$ 800$ million in 2011.Said Salim Awadh Bakhresa is a Tanzanian business tycoon. He is the founder and the chairperson of Bakhresa Group of Companies. He is well known industrialist in the mainland Tanzania and the Island of Zanzibar. As of 2020, Bakhresa net worth is about $\$ 800$ million. Currently, it is estimated that his net worth is $\$ 10.5$ Billion according to what he is invested added up. 
Table: Comparative analysis of constraints Bakhresa Group of Company running the business, grading

Difficulties on regulations, grading quality of service offered by institutions and evaluation problems impacts.

\begin{tabular}{|c|c|c|c|c|}
\hline & $\begin{array}{l}\text { Nyamagana } \\
\text { Council }\end{array}$ & & $\begin{array}{l}\text { Ilemela } \\
\text { Council }\end{array}$ & \\
\hline Variable & Frequency & Percentage \% & Frequency & Percentage \% \\
\hline Difficulty firm registration regulations & 84 & 45.9 & 99 & 54.1 \\
\hline Lack of government assistance & 46 & 68.7 & 21 & 31.3 \\
\hline Capital constraints & 35 & 48.6 & 37 & 51.4 \\
\hline Limited support to commercial enterprise & 15 & 35.7 & 27 & 64.3 \\
\hline Lack of access to records on authorities policies & 104 & 52.8 & 93 & 47.2 \\
\hline Lack of new technology & 101 & 47.6 & 111 & 52.4 \\
\hline Lack of expert association and affiliation & 111 & 89.5 & 13 & 10.5 \\
\hline Limited access to providers & 140 & 84.8 & 25 & 15.2 \\
\hline Competition in domestic market & 98 & 60.1 & 65 & 39.9 \\
\hline Limited access to statistics on marketplace & 91 & 56.2 & 71 & 43.8 \\
\hline Lack of Government packages & 62 & 37.8 & 102 & 62.2 \\
\hline Lack of credit score from banks & 90 & 51.4 & 85 & 48.6 \\
\hline Lack of access to customers & 101 & 48.1 & 109 & 51.9 \\
\hline Lack access to facts of technologies & 95 & 58.6 & 67 & 41.4 \\
\hline $\begin{array}{l}\text { Difficulty license for begin of } \\
\text { business regulations }\end{array}$ & 17 & 50 & 17 & 50 \\
\hline Lack of market knowledge & 12 & 30.8 & 27 & 69.3 \\
\hline Difficulty employment regulations & 22 & 31.9 & 12 & 17.4 \\
\hline Difficulty health and protection policies & 22 & 31.9 & 47 & 68.1 \\
\hline Difficulty tax rules regulations & 35 & 37.2 & 59 & 62.8 \\
\hline Difficulty environmental guidelines & 11 & 33.3 & 22 & 66.7 \\
\hline Difficulty customs policies regulations & 16 & 34.0 & 31 & 66.0 \\
\hline Lack of statistics on market possibilities & 22 & 16.9 & 108 & 83.1 \\
\hline Limited access to facts on finance & 39 & 49.4 & 40 & 50.6 \\
\hline Ensuring guarantees for bank loans & 95 & 52.8 & 85 & 47.2 \\
\hline High interest prices on bank loans & 115 & 54.8 & 95 & 45.2 \\
\hline Competition in overseas market & 21 & 37.5 & 35 & 62.5 \\
\hline $\begin{array}{l}\text { Electricity provider - TANESCO quality of } \\
\text { service offered }\end{array}$ & 36 & 39.1 & 56 & 60.9 \\
\hline Imperfect competition "black marketplace" & 67 & 41.4 & 95 & 58.6 \\
\hline The smuggling of foreign items & 113 & 49.1 & 117 & 50.9 \\
\hline Police quality of service offered & - & - & 61 & 42.4 \\
\hline $\begin{array}{l}\text { Telecommunication services vendors quality of } \\
\text { service offered }\end{array}$ & 57 & 35.9 & 102 & 64.2 \\
\hline Court of businesses quality of service offered & 95 & 47.7 & 104 & 52.3 \\
\hline Long mortgage utility processing & 109 & 59.2 & 75 & 40.8 \\
\hline $\begin{array}{l}\text { Water provider - DAWASCO quality of service } \\
\text { offered }\end{array}$ & 116 & 49.6 & 118 & 50.4 \\
\hline Chamber of commerce quality of service offered & 112 & 48.7 & 118 & 51.3 \\
\hline
\end{tabular}

Source: Researcher, 2019

\section{CONCLUSION AND RECOMMENDATION}

\subsection{Conclusion}

Bakhresa group is among the most successful company which operate in Tanzania and other different African countries and World Wide. All these successes are due to well established structure of a company. The members of the organization are made to serve these goals and reward are given to motivate them. On the one hand Bakhresa Group supports the innovation and creativity. It has spent enormous sums of money trying to develop an environment that fosters innovation. Also, the company creates a good product from manufacturing food and beverage to all other sector which keeps the good reputation of the company. Due to all this the Bakhresa Group becomes a market leader because of innovation and entrepreneurship. 


\subsection{Recommendation for Further research}

The research we were conducting basically in Bakhresa Group of Company in Mwanza region in Tanzania. Whereby there should be an improvement in many sectors for further improvements in the Company. These sectors are such like Infrastructure especially energy, road and rail network and ports. The region should come together and mobilize some resources to develop infrastructure as this is critical to how competitive we are as a business (Bakhresa) / Country (Tanzania) / Region (Mwanza). Also, they should improve trade facilitation in terms of streamlining the functions and number of regulatory authorities and reducing non-tariff barriers like police roadblocks and weighbridges this will decrease the cost of doing business and facilitate trade. Regular engagement with the business society in order to keep appraised of the problems affecting us in doing business is important and will allow for timely response. In additional, in a specific place a Company must develop strategic tactics in Agriculture so as a Country and as a Region. They are net importers of grain, especially wheat, apart from that the region has vast arable land that can be utilized.

\section{REFERENCE}

Abo, T. (2000) 'Spontaneous Integration in Japan and East Asia: Development, Crises and Beyond', in G.L. Clark, M.P. Feldman and M.S. Gertler (eds.) The Oxford Handbook of Economic Geography, Oxford University Press: Oxford, pp: 625-648.

Amin, A. (2000) 'The European Union as more than a Triad Market for National Economic Spaces', in G.L. Clark, M.P. Feldman and M.S. Gertler (eds.) The Oxford Handbook of Economic Geography, Oxford University Press: Oxford, pp: 671-687.

Antonelli, C. (2000) 'Restructuring and Innovation in Long-Term Regional Change', in G.L. Clark, M.P. Feldman and M.S. Gertler (eds.) The Oxford Handbook of Economic Geography, Oxford University Press: Oxford, pp: $395-412$.

Asheim, B.T. (2000) 'Industrial Districts; The Contributions of Marshall and Beyond', in G.L. Clark, M.P.

Feldman and M.S. Gertler (eds.) The Oxford Handbook of Economic Geography, Oxford University Press: Oxford, pp: 413-431.

Auderetsh, D.B. (2000) 'Corporate Form and Spatial Form', in G.L. Clark, M.P. Feldman and M.S. Gertler (eds.)

The Oxford Handbook of Economic Geography, Oxford University Press: Oxford, pp: 333-351.

Berg, D.M. and Guisinger, S.E. (2001) 'Capital flows, capital controls and international business risk', in A.M.

Rugman and T.L. Brewer (eds.) The Oxford Handbook of International Business, Oxford University Press: Oxford, pp: 259-281.

Birkenshaw, J. and Hood, N. (2000) 'Characteristics of foreign subsidiaries in industry clusters', Journal of International Business Studies 31(1): 141-15

Buckley, P.J. and Ghauri, P.N. (2002) International Mergers and Acquisitions, International Thomson Business Press: London

Cairncross, F. (1997) The Death of Distance: How the Commu- nications Revolution Will Change our Lives, Harvard Business School Press: Boston, MA.

Buckley, P.J. (2002) 'Is the international business research agenda running out of steam?', Journal of International Business Studies 33(2): 365-373.

Buckley, P.J. and Carter, M.J. (2002) 'Process and structure in knowledge management practices of British and US multi- national enterprises', Journal of International Management 8(1): 29-48.

Edgington, D.W. and Hayet, R. (2000) 'Foreign direct invest- ment and the flying geese model: Japanese electronics firms in the Asia Pacific', Environment and Planning A 32(2): 281-304

Feldman, M.P. (2000) 'Location and Innovation: The New Economic Geography of Innovation, Spillovers and Agglom- eration', in G.L. Clark, M.P. Feldman and M.S. Gertler (eds.) The Oxford Handbook of Economic Geography, Oxford University Press: Oxford, pp: 373-395.

Frost, T.S. (2001) 'The geographical source of foreign sub- sidiaries' innovation', Strategic Management Journal 22(2): 101-123.

Gersbach, H. (2002) 'Does and how does globalisation matter at industry level?', World Economy 25(2)

Gersbach, H. (2002) 'Does and how does globalisation matter at industry level?', World Economy 25(2): 209-

Ghauri, P.N. and Buckley, P.J. (2002) 'Globalization and the End of Competition: A Critical Review of RentSeeking Multi- nationals', in V. Havila, M. Forsgren and H. Ha kansson (eds.) Critical Research on Multinational Corporations, Pergamon Press: Oxford, pp: 7-28.

http://azammarine.com/aboutus.html 